\title{
Gut-central nervous system axis is a target for nutritional therapies
}

\author{
Gustavo D Pimentel ${ }^{1,6^{*}}$, Thayana O Micheletti ${ }^{2}$, Fernanda Pace ${ }^{1}$, José C Rosa ${ }^{3}$, Ronaldo VT Santos ${ }^{4}$ and \\ Fabio S Lira ${ }^{5}$
}

\begin{abstract}
Historically, in the 1950s, the chemist Linus Pauling established a relationship between decreased longevity and obesity. At this time, with the advent of studies involving the mechanisms that modulate appetite control, some researchers observed that the hypothalamus is the "appetite centre" and that peripheral tissues have important roles in the modulation of gut inflammatory processes and levels of hormones that control food intake. Likewise, the advances of physiological and molecular mechanisms for patients with obesity, type 2 diabetes mellitus, inflammatory bowel diseases, bariatric surgery and anorexia-associated diseases has been greatly appreciated by nutritionists. Therefore, this review highlights the relationship between the gut-central nervous system axis and targets for nutritional therapies.
\end{abstract}

Keywords: Gut, Central nervous system, Nutrition, Diet, Appetite, Inflammatory disease

\section{Introduction}

The energy balance is determined by the relationship between the acquisition and expenditure of energy. This perfect interaction occurs among physiological signals in peripheral organs and the central nervous system (CNS). Apart from the obvious digestive and absorptive functions of the gastrointestinal tract, gut and adipose tissue hormones play an important role in controlling the energy balance, particularly via the regulation of food intake in both the short- and long-term, respectively. Therefore, the enteric nervous system (ENS), gut hormones, and nutrients act in the control process at the beginning and termination of meals [1,2].

The CNS-gut axis is controlled by the ENS and its importance in the health and disease has been recognised by several studies [3,4]. According to health professionals, advances in the physiological and molecular mechanisms involving the ENS are responsible for the control of the energy balance, and for the nutritional therapies used in patients with obesity, type 2 diabetes mellitus, inflammatory bowel diseases (IBDs), bariatric surgery and cancer-associated anorexia [5-9].

\footnotetext{
* Correspondence: gupimentel@yahoo.com.br

'Department of Internal Medicine, Faculty of Medical Sciences, State

University of Campinas (UNICAMP), Campinas, SP, Brazil

Full list of author information is available at the end of the article
}

In the 1950s, the chemist Linus Pauling established a relationship between decreased longevity and obesity [10]. At this time, with the advent of studies involving the mechanisms that modulate appetite control, it was recognised that the hypothalamus is the "appetite centre". In rats, some researchers observed that lesions in the lateral hypothalamus produced anorexia (hunger centre) and lesions in the ventromedial nuclei of the hypothalamus produced obesity (satiety centre) [11-14].

More recently, the discovery of cloned leptin in 1994, which is produced and secreted by adipose tissue, provided some evidence that appetite control could also be modulated by peripheral tissues [15].

In relation to the mechanisms of intestinal hormonal action, the beginning of the food intake process results in the release of anorexigenic hormones, such as peptide YY (PYY), the glucagon-like peptide 1 (GLP-1), oxyntomodulin (OXM), the glucose-dependent insulinotropic polypeptide (GIP), cholecystokinin (CCK) and prouroguanylin (Figure 1). Likewise, the CNS receives and integrates several factors, adjusting the energy balance in accordance with energetic necessity. Overall, the secretion of anorexigenic hormones (including PYY, GLP-1, OXM, GIP, CCK and prouroguanylin) and the activation of neuropeptides, such as POMC and CART, occurs in the postprandial state. On the other hand, the greater 


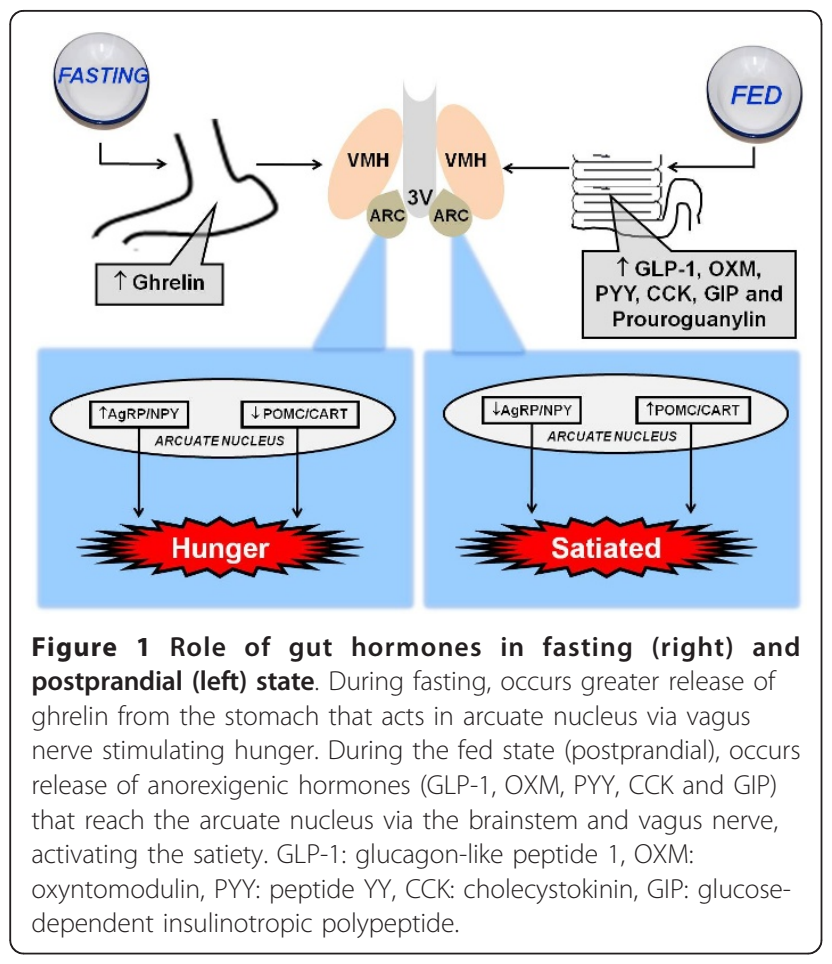

release of the orexigenic hormone ghrelin and the activation of the neuropeptides AgRP and NPY occurs in the fasting state [16-18] (Figure 1). In the next step, the main gut hormones that influence energy homeostasis are summarised (Table 1).

For nutrition professionals, the gut-CNS axis is considered an attractive opportunity, because foods may help to treat and prevent diseases. In this review, we discuss the fact that nutritional therapies could modify the gut flora and may reach the CNS in order to modulate the food intake and inflammatory processes. Some nutritional therapies that are known to modulate the gut-CNS axis via physiological and molecular mechanisms are also discussed.

\section{The main underlying mechanisms behind the connection} between microbiota and the central nervous system

The components that interact to form this complex brain-gut communication is bidirectional, with stimuli from gastrointestinal tract (GIT) that influences the brain functions and messages from the brain that may alter some GIT activities, such as motor, sensory and secretory [19]. It was demonstrated that this link occurs via the vagus nerve to the brainstem, and via spinal afferents to the spinal cord [20]. Recently, Bravo et al. [21] showed that vagotomized mice did not exhibit behavioral and neurochemical effects that L.rhamnosus exerts in CNS, evidencing the correlation of the vagus nerve in the direct communication between the bacteria and the brain.

Moreover, the serotonin (5-HT) levels and hypothalamic-pituitary-adrenal (HPA) axis may also participate in this connection. All connections are involved with modulation of infections and inflammatory diseases, such as obesity, type 2 diabetes mellitus, ulcerative colitis, Crohn's disease, as well as with behavioural problems and psychiatric disorders, such as cognition, mood, emotion, stress and anxiety $[21,22]$.

\section{Diets and microbiota: A general overview}

The microbes that reside in the gut favors the harvest of energy from food, influence the metabolic profiling of organs and exerts nutritional and protective effects on the intestinal epithelium and immune system [23-25].

Table 1 Summary of the main gut hormones that influence the energy homeostasis

\begin{tabular}{|c|c|c|}
\hline Gut hormones (receptor) & Secretion site & Action \\
\hline PYY (G protein-coupled receptors) & L cells of gut & $\downarrow$ food intake and delays gastric emptying \\
\hline GLP-1 (GLP-1R) & $L$ cells of gut & $\begin{array}{c}\downarrow \text { food intake, releases insulin, hand out as incretin, } \downarrow \text { glucose levels and delays gastric } \\
\text { emptying }\end{array}$ \\
\hline OXM (GLP-1R) & $L$ cells of gut & $\downarrow$ food intake \\
\hline CCK (CCK1 and CCK2) & $\begin{array}{l}\text { I cell of small } \\
\text { intestine }\end{array}$ & $\downarrow$ food intake \\
\hline $\begin{array}{l}\text { Uroguanylin and Guanylin } \\
\qquad(\text { GUCY2CR) }\end{array}$ & $\begin{array}{l}\text { Intestinal epithelial } \\
\text { cells }\end{array}$ & $\downarrow$ food intake \\
\hline GIP & $K$ cells of gut & $\downarrow$ food intake and glucose levels \\
\hline PP (Y4 and Y5) & PP cells of pancreas & $\downarrow$ food intake \\
\hline Amylin (AMY 1-3) & $\beta$ cells of pancreas & $\downarrow$ glucose levels \\
\hline Insulin (IR) & $\beta$ cells of pancreas & $\downarrow$ food intake and glucose levels \\
\hline Glucagon (GCGR) & $\alpha$ cells of pancreas & $\uparrow$ glucose levels and insulin secretion \\
\hline Ghrelin (GHSR1) & Stomach & $\uparrow$ food intake \\
\hline
\end{tabular}

PYY: peptide tyrosine tyrosine; GLP-1: glucagon-like peptide 1; PP: pancreatic polypeptide; OXM: oxyntomodulin; CCK: cholecystokinin; GHSR1: growth hormone secretagogue; GUCY2C receptors: guanylyl cyclase 2 C receptors; IR: insulin receptor; GIP: glucose-dependent insulinotropic peptide. 
Moreover, the microbiota consists mainly of bacteria that are divided in two main phylotypes: Bacteroidetes and Firmicutes [26,27].

Supporting normal digestion and host metabolism, gut microbiota is able to expand nutrient availability, releasing energy through fermentation of otherwise non-digestible oligosaccharides or by modulating absorption. The short chain fatty acids (SCFA), which are the major metabolic products of anaerobic bacteria fermentation, are an important energy source for humans, being used by colonocytes, liver and muscle. It has been reported that 5 to $10 \%$ of human basal energy requirements are provided by SCFA [28-31].

Since the interactions of microbes with host leads to a complex balance of host genes, alteration of microbiota population can cause several metabolic disorders.

Recently, Cryan \& O'Mahony [19] suggested that numerous conditions may modify the microbiota, such as obesity, IBDs, antibiotics, infections and diets [22,32]. Therefore, the roles of the gut-CNS axis on metabolic diseases, focusing on the physiological and nutritional aspects are summarised in the Figure 2.

\section{Obesity and type 2 diabetes mellitus}

Since it is known that the microbiota is related to energy homeostasis, digestion of nutrients and metabolism, some low-grade inflammation-related diseases have emerged as an attractive opportunity for researchers.

The first studies to observe that obese microbiota have an enhanced ability to absorb energy from the diet were described by Jeffrey Gordon's group [33,34].

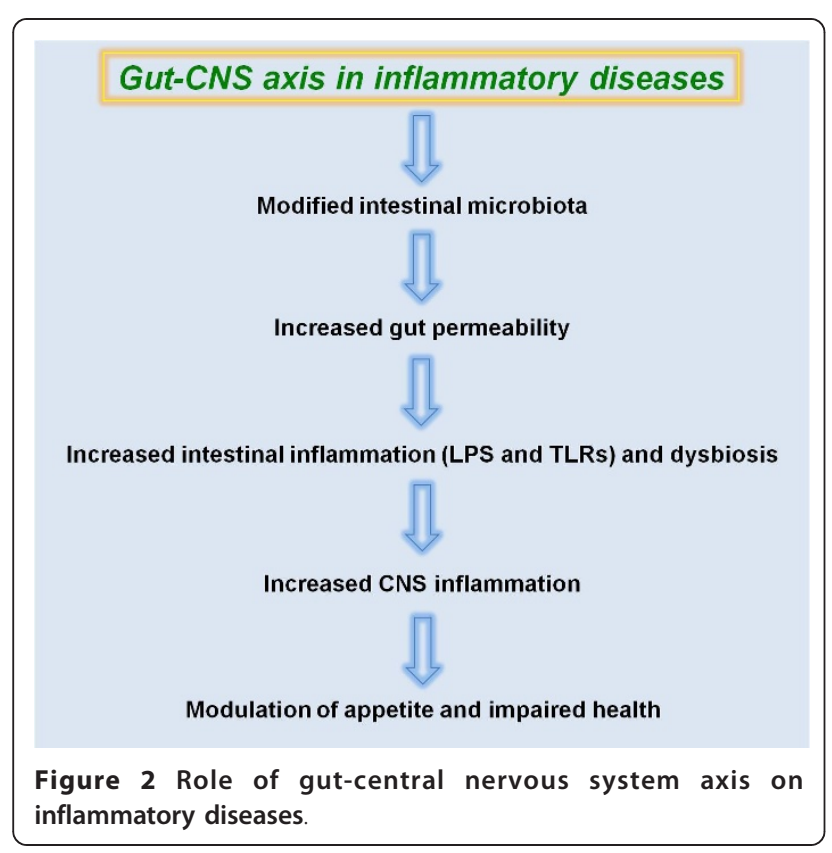

Cani et al. [35] proposed that both obesity and type 2 diabetes mellitus can be characterised by increased lipopolysaccharide (LPS) levels. For instance, in the presence of diet induced obesity (DIO), the LPS concentrations are higher than in the fasting state. In addition, either DIO animals or those submitted to subcutaneous injections of LPS represent enhanced LPS-containing microbiota, as well as glucose and body weight gain. Likewise, these authors were the first to demonstrate that "metabolic endotoxaemia" initiates obesity [35].

Recently, it has been shown that food rich in saturated or trans-fatty acids stimulates inflammatory markers [9,36-40]. Raybould [41] suggests that intestinal inflammation is associated with obesity due to high LPS levels. In 2011, it was shown that the ingestion of trans fatty acids during gestation and lactation led to an increase in blood LPS levels, the activation of inflammatory signalling in the hypothalamus and an increased food intake in adult offspring rats [9]. Moreover, the same studies $[27,42]$ observed the presence of intestinal inflammation in different models of obesity, such as eating a high-fat diet, rich in saturated fatty acids and genetic obesity.

When evaluating inflammatory markers in CONV mice fed with a high-fat diet, Ding et al. [43] observed increased body weights and activation of gut TNF- $\alpha$ mRNA expression. Likewise, Caricilli et al. [27] showed increased blood LPS levels in toll-like receptor 2 (TLR2)-deficient mice when compared to wild-type mice. TLR2 deficient mice showed activated phosphorylation of janus kinase (JNK), TLR4 and phosphorylation in serine of the insulin receptor substrate-1 of several tissues [27]. In this work, the authors suggest that an increase in LPS levels together with TLR4, in the absence of changes of TLR2, result in a compensatory action that may lead to increased activation of TLR4. Together, this would contribute to insulin resistance in TLR2-deficient mice [27]. Likewise, in a previous study [9] performed with adult offspring rats from mothers fed trans fatty acids during gestation and lactation, increased blood LPS levels and hypothalamic TLR4 expression were seen with no change to hypothalamic TLR2 expression. Moreover, the increase of blood LPS provoked by a high-fat diet has also been shown by other recent studies $[44,45]$. It has also been shown that the actions of fatty acids are aggravated by physiological ligands of G-protein-coupled receptors, such as GPR40, $41,43,84$ and 119 , and, therefore, it may be involved in the progression of several inflammatory diseases [46].

Another TLR described to influence microbiota is TLR5. Vijay-Kumar et al. [47] demonstrated that mice deficient in TLR5 exhibit obesity, hyperphagia, dyslipidaemia, hypertension and insulin resistance, and that they also show an altered composition of gut 
microbiota, such as increased Firmicutes (54\%) and lower Bacteroidetes (39.8\%).

In addition to inflammatory processes, non-alcoholic fatty liver disease (NAFLD) is a typical hepatic manifestation that has been found to be obesity-related. Recently, inflammasome-deficient mice were shown to have modifications of gut microbes population through the influx of TLR4 and TLR9 agonists into the portal circulation. Therefore, increased hepatic inflammation levels can lead to the development of NAFLD and obesity [48].

An important study that demonstrated the relationship between intestinal bacterial and obesity in humans was published by Wu et al. in 2011 [49]. In this study, it was found that an increased fat intake and low dietary fibre are associated with the modulation of intestinal microbiota. The authors of this study showed that animal proteins and saturated fatty acids are associated with increased Bacteroidetes levels, and that diets containing carbohydrates but lacking meat and dairy products increased Prevotella levels. Together, these facts create a profile of weight gain and gut inflammationrelated bacteria.

DIO experimental models also indicate low expression of tight junction proteins in the gut, and the increasing in intestinal permeability [41]. Brun et al. [50] found in either $o b / o b$ and $d b / d b$ mice, an alteration in the intestinal permeability same when mice were submitted to standard chow consumption. In rats fed with hyper-lipidic diet also was observed an increase of intestinal permeability through the reduction of tight junction proteins, such as claudin 1 , claudin 3 and junctional adhesion molecule-1 [51].

Collectively, several obesity models have observed that a major determinant of intestinal permeability is the intercellular tight junction proteins. Tight junctions are organised by the same transmembrane proteins, such as occludin, claudin and junctional adhesion molecule-1 [52-54]. Therefore, these transmembrane proteins interact with Zonula Occludens (ZO-1-3), which anchors the transmembrane proteins [55] provoking an increase of intestinal permeability. The increased intestinal permeability is thought to be associated with a higher activity of pathogenic bacteria and inflammatory processes. In summary, some studies have described that the main tight junction proteins responsible for this intestinal permeability are ZO-1, myosin light chain, occludin, claudin and junctional adhesion molecule $1[44,50,52-54,56,57]$.

Several papers suggest that saturated fatty acids might enhance the blood LPS levels through GPRs, possibly secreted by gut cells, may affect the CNS and alter numerous central inflammatory markers. In addition, the increased intestinal permeability aggravated by a high-fat diet and LPS may also be responsible for altered epithelial barrier function, and it is therefore possible that the high prevalence of obesity and type 2 diabetes mellitus is connected with an altered gut microbiotaCNS axis.

\section{Bariatric surgery}

In the middle of the 1950 s, Kremen et al. [58] postulated that bypass surgery in dogs reduced food absorption. Recently, in humans, bariatric surgery has been found to be a procedure which results in patients rapidly losing weight, accompanied by the resolution of type 2 diabetes mellitus and a reduction of cardiovascular deaths $[45,59]$. However, the mechanisms underlying the improvement of metabolic parameters have not been fully elucidated. Likewise, Evans et al. [60] have shown that obese patients had an increase of blood PYY levels and GLP-1 was restored to normality after gastric bypass surgery compared to patients with normal weights. Short-term Rouxen-Y gastric bypass (six months) was able to activate PYY and GLP-1 secretion, and stimulated the satiety in response to a liquid-meal intake in normal, glucose-tolerant obese patients [61]. Falkén et al. [62] reported that patients had a progressive rise of the GLP-1 and OXM concentrations after gastric bypass and that this procedure favours weight loss and improved insulin sensitivity.

Collectively, the published data has shown that, after bariatric surgery, numerous gut hormones can reduce the appetite and normalise glucose homeostasis, and that the main actions are modulated through GLP-1, PYY, OXM, ghrelin, insulin and leptin [63]. Moreover, an increased secretion of anorexigenic hormones, such as GLP-1 and PYY occurs with bariatric surgery (Figure $3)$. It is also possible to speculate that the bariatric surgery might modulate the intestinal permeability and enhancement of anorexigenic gut hormone secretion, alongside the reduction of inflammation seen in obese

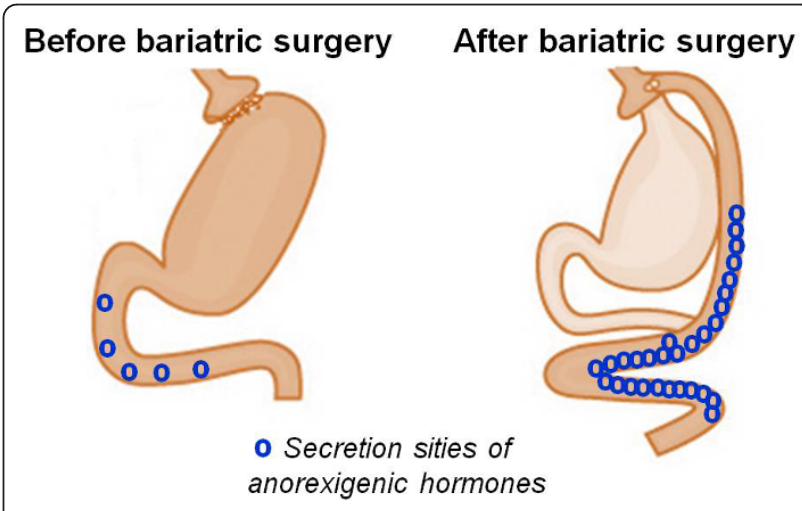

Figure 3 Secretion sities of anorexigenic hormones, such as glucagon-like peptide 1 (GLP-1) and peptide YY (PYY) are increased after bariatric surgery. 
patients, but this has not been evaluated. Collectively, it is known that theses anorexigenic hormones might activate POMC and CART neuropeptides in order to reduce the food intake and body weight, and also help to moderate energy expenditure.

\section{Inflammatory bowel diseases (IBDs)}

The IBDs, that affect the health of humans, include ulcerative colitis, Crohn's disease and irritable bowel syndrome (IBS) [64-66]. Macfarlane et al. [67] have suggested that the appearance of these diseases may be due to modified gut microbiota, or as a consequence of local inflammation. However, a recent study has shown that the intestinal wall of either inflamed or non-inflamed guts [68] may be associated with severe disease. Likewise, human studies of patients diagnosed with IBDs have observed increased TLR2, TLR4 and TLR5 expression in the gut wall $[69,70]$, and other studies have reported an increase of the IL-6, IL-8, TNF- $\alpha$ and interferon-gamma levels [71-73]. Therefore, it is possible to observe that in IBDs that have an inflammatory status higher than that of obesity, more severe disease symptoms are seen. In order to investigate the effects of neuro-inflammation in animals submitted to experimental IBD, Wang $\mathrm{K}$, et al. [74] observed increased IL-6 mRNA expression in both the colon and brain of these animals when compared to control animals.

Collectively, it can be speculated that higher levels of gut-related inflammation lead to a reduction of food intake and malnutrition due to the activation of cytokines in the CNS. According to Pavlov \& Tracey [75], the autonomic nervous system plays a key role in the control of the brain in moderating the immune system and inflammation.

In summary, several studies have reported that inflammatory bowel problems are linked to a reduction of $\mathrm{Lac}$ tobacillus spp and Bacteroidetes, and an increase of the Firmicutes-Bacteroidetes ratio [76-79]. These changes in intestinal flora are aggravated through alterations in the immune system that underlie disease pathogenesis.

\section{Nutritional therapies that improve metabolic diseases through the gut-CNS axis}

While microbes have been used to study the underlying mechanisms of inflammatory diseases and insulin resistance, numerous researchers have also stated that nutritional components could be used as a strategy to combat the gravity of these abnormalities. Historically, the Greek physician Hippocrates, "The father of medicine", reportedly said "Let your food be your medicine, and your medicine be your food".

Among the nutritional components that support a healthy intestinal microbiota, we highlight the dietary fibres, probiotics and prebiotics [80-84]. The improvements include a reduction of systemic and local inflammation, as well as less intestinal pain and discomfort, when both probiotics and prebiotics are used $[80,85,86]$. In addition, other studies have shown an inhibition of bacterial translocation and a reduction of intestinal permeability with the use of these nutrients $[87,88]$.

One study demonstrated that the use of oligofructose, a prebiotic, enhanced the levels of Bifidobacterium spp., and improved insulin sensitivity, as well as restoring inflammatory status through decreased endotoxaemia metabolism [80].

Oligofructose and resistant starches have been demonstrated to increase short-chain fatty acid-induced GLP-1 expression [89], and to reduce ghrelin expression [90]. Moreover, in a recent review the nutrients and diets that stimulate the anorexigenic gut peptides, reduce the food intake and break off the obesity were summarised. The main nutrients and diets that can increase the GLP-1, CCK, GIP, OXM and PYY secretion are dietary fibre, dairy products, unsaturated fatty acids and a normal calorie diet [2].

Recently, it was observed that a prebiotic-enriched diet reduced Firmicutes and increased Bacteroidetes levels, as well as improving glucose sensitivity, body fat, inflammation and oxidative stress [91]. Furthermore, a recent review suggested that SCFA providers provided of dietary fibers, such as propionate and butyrate, induce the reduction of food intake by increasing leptin secretion and reducing pro-inflammatory cytokine expression [92]. These dietary fibres are fermented by microbiota, and higher butyric acid levels were found in animals fed with diets containing a mixture of oligofructose and raffinose [93].

Necrotising pancreatitis patients with diarrhoea received semi-elemental nutrients via jejunal feeding, and an increase in faecal short-chain fatty acids, such as acetate, propionate and butyrate were found when compared to pre-treatment levels. In addition, a resolution of diarrhoea episodes was seen in approximately $66 \%$ of patients. Therefore, this study suggests that dietary fibre supplementation is an excellent method for the improvement of healthy intestinal microbiota, and results in reduced symptoms of dysbiosis [81].

Concomitant to numerous "healthy" nutrients, it is possible that unsaturated fatty acids, such as omega-3, are an attractive option for the improvement of inflammatory processes, and that this can be modulated by the physiological ligand of these fatty acids, GPR120 [94,95].

In relation to high-grade inflammatory diseases, such as a provoked by Human Immunodeficiency Virus type1 (HIV-1), patients were shown to have infections in lymphoid tissue, alterations of intestinal microbiota and impaired symptoms of Acquired Immunodeficiency 
Syndrome (AIDS). Therefore, the use of probiotic diets is suggested for the prevention of progression of HIVlinked infections [96].

It has been recognised that obese, insulin-resistant and IBD subjects represent a group requiring moderation of intestinal microbiota due to a higher risk of the development of cancer. This is because the mechanisms by which intestinal bacteria induce carcinogenesis are thought to be via chronic inflammation, immune system evasion and immunosuppression. Conversely, the probiotics used have also emerged as an possible mechanism for the reduction of the pro-inflammatory status seen in cancer patients [97].

Collectively, this topic has summarised the main physiological and metabolic alterations that modify illnesses of the gut both before and after nutritional therapy (Figure 4).

Although nutritional compounds are important for the improvement of health, changes to diets, such as an increase of either fruit or vegetable consumption, as well as a reduction of refined carbohydrates and saturated and trans-fatty acids $[98,99]$, are required, as food restriction can prevent obesity in humans $[98,99]$ and mice deficient in the TLR5 [47]. Furthermore, micronutrients and macronutrients from existing diets are targets for gut health and strengthening of the immune system [100].

The studies discussed in this review collectively support the emerging view that microbiota contribute to metabolic disease, and suggest that an impaired diet quality may promote the development of inflammatory diseases. However, some nutrients that have been studied, such as dietary fibres, and probiotic and prebiotic nutrients, along with bariatric surgery, are one possible option for the maintenance of intestinal health, and the improvement of the gut-CNS axis (Figure 5).

In summary, the discoveries in understanding these foods and nutrients could help to regulate the gut-CNS axis, but remain a challenge for nutritionists and

\begin{tabular}{|l|l|}
\hline $\begin{array}{c}\text { Gut sick } \\
\text { Without nutritional therapies }\end{array}$ & \multicolumn{1}{c|}{$\begin{array}{c}\text { Gut health } \\
\text { With nutritional therapies }\end{array}$} \\
& $\downarrow$ \\
& \\
$\uparrow$ Inflammatory mediators & \\
$\uparrow$ Bacterial translocation & $\downarrow$ Inflammatory mediators \\
$\uparrow$ Intestinal permeability & $\downarrow$ Bacterial translocation \\
$\uparrow$ Firmicutes & $\downarrow$ Intestinal permeability \\
$\downarrow$ Bacteroidetes & $\downarrow$ Firmicutes \\
$\downarrow$ Insulin sensibility & $\uparrow$ Bacteroidetes \\
Figure 4 Summary of main physiological and metabolic & $\uparrow$ Insulin sensibility \\
alterations that modify the gut sick and health before and \\
after the nutritional therapies.
\end{tabular}

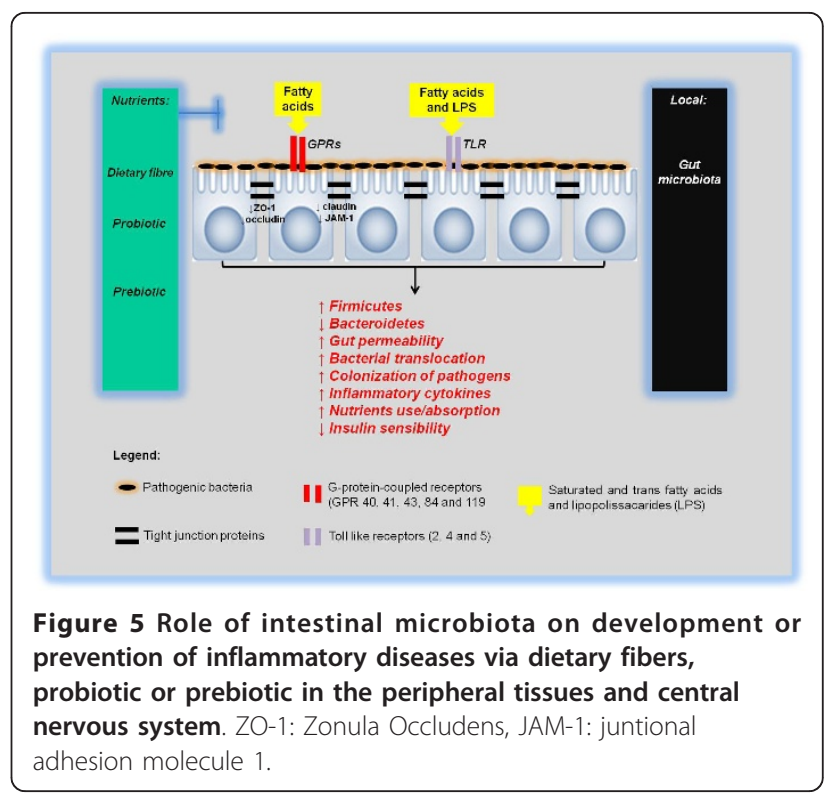

scientific investigators. Therefore, future research must be focused on looking to improve the effectiveness of diets for the prevention of inflammation between the gut-CNS axis, as well as for the maintenance of microbial homeostasis of the gut.

\section{Acknowledgements}

This work was supported by Fundação de Amparo à Pesquisa do Estado de São Paulo (FAPESP), Brazil and Conselho Nacional de Desenvolvimento

Científico e Tecnológico (CNPq), Brazil.

\section{Author details}

${ }^{1}$ Department of Internal Medicine, Faculty of Medical Sciences, State University of Campinas (UNICAMP), Campinas, SP, Brazil. ${ }^{2}$ Faculty of Applied Science, State University of Campinas (UNICAMP), Limeira, SP, Brazil.

${ }^{3}$ Department of Physiology and Biophysics, Institute of Biomedical Sciences I, University of São Paulo (USP), São Paulo, SP, Brazil. ${ }^{4}$ Department of Psychobiology, Federal University of São Paulo (UNIFESP), São Paulo, SP, Brazil. ${ }^{5}$ Laboratory of Exercise Biochemistry and Physiology, Health Sciences Unit, University of Southern Santa Catarina (UNESC), Criciúma, SC, Brazil. ${ }^{6} J$ osé Caetano de Lima, 682. Bairro Junqueira, Lins MA: 16403-162, SP, Brazil.

\section{Authors' contributions}

GDP performed the design of the study, researched and discussed the articles and written the paper. TOM, FP, JCR, RVTS and FSL also researched and discussed the papers. All authors read and approved the final version manuscript.

\section{Competing interests}

The authors declare that they have no competing interests.

Received: 19 August 2011 Accepted: 10 April 2012

Published: 10 April 2012

\section{References}

1. Pimentel GD MJ, Mota JF, Oyama LM: Oxintomodulina e obesidade. Rev Nutr 2009, 22:727-737.

2. Pimentel GD, Zemdegs JC: [Foods and nutrients modulates the release of anorexigenic gastrointestinal hormones]. Acta Med Port 2010, 23:891-900.

3. Mayer EA: Gut feelings: the emerging biology of gut-brain communication. Nat Rev Neurosci 2011, 12:453-466. 
4. Washington MC, Raboin SJ, Thompson W, Larsen CJ, Sayegh Al: Exenatide reduces food intake and activates the enteric nervous system of the gastrointestinal tract and the dorsal vagal complex of the hindbrain in the rat by a GLP-1 receptor. Brain Res 2010, 1344:124-133.

5. Inui A, Asakawa A, Bowers CY, Mantovani G, Laviano A, Meguid MM, Fujimiya M: Ghrelin, appetite, and gastric motility: the emerging role of the stomach as an endocrine organ. FASEB J 2004, 18:439-456.

6. Hobson KG, Havel PJ, McMurtry AL, Lawless MB, Palmieri TL, Greenhalgh DD: Circulating leptin and cortisol after burn injury: loss of diurnal pattern. J Burn Care Rehabil 2004, 25:491-499.

7. Laviano A, Meguid MM, Rossi-Fanelli F: Improving food intake in anorectic cancer patients. Curr Opin Clin Nutr Metab Care 2003, 6:421-426.

8. Thaler JP, Choi SJ, Schwartz MW, Wisse BE: Hypothalamic inflammation and energy homeostasis: resolving the paradox. Front Neuroendocrinol 2010, 31:79-84.

9. Pimentel GD, Lira FS, Rosa JC, Oliveira JL, Losinskas-Hachul AC, Souza Gl, das Gracas TdCM, Santos RV, de Mello MT, Tufik S, et al: Intake of trans fatty acids during gestation and lactation leads to hypothalamic inflammation via TLR4/NFkappaBp65 signaling in adult offspring. J Nutr Biochem 2012, 23:265-271.

10. Pauling L: The Relation between Longevity and Obesity in Human Beings. Proc Natl Acad Sci USA 1958, 44:619-622.

11. Hetherington AW RS: Hypothalamic lesions and adiposity in the rat. Anat Rec 1940, 78:149-172.

12. Anand BK, Brobeck JR: Hypothalamic control of food intake in rats and cats. Yale J Biol Med 1951, 24:123-140.

13. Teitelbaum P, Stellar E: Recovery from the failure to eat produced by hypothalamic lesions. Science 1954, 120:894-895.

14. Miller NE: Experiments on motivation. Studies combining psychological, physiological, and pharmacological techniques. Science 1957, 126:1271-1278.

15. Zhang $Y$, Proenca R, Maffei M, Barone M, Leopold L, Friedman JM: Positional cloning of the mouse obese gene and its human homologue. Nature 1994, 372:425-432.

16. Leibowitz SF, Wortley KE: Hypothalamic control of energy balance: different peptides, different functions. Peptides 2004, 25:473-504

17. Schwartz MW, Woods SC, Porte D Jr, Seeley RJ, Baskin DG: Central nervous system control of food intake. Nature 2000, 404:661-671.

18. Valentino MA, Lin JE, Snook AE, Li P, Kim GW, Marszalowicz G, Magee MS, Hyslop T, Schulz S, Waldman SA: A uroguanylin-GUCY2C endocrine axis regulates feeding in mice. J Clin Invest 2011, 121:3578-3588.

19. Cryan JF, O'Mahony SM: The microbiome-gut-brain axis: from bowel to behavior. Neurogastroenterol Motil 2011, 23:187-192.

20. Mayer EA: Gut feelings: the emerging biology of gut-brain communication. Nat Rev Neurosci 2011, 12:453-466.

21. Bravo JA, Forsythe P, Chew MV, Escaravage E, Savignac HM, Dinan TG, Bienenstock J, Cryan JF: Ingestion of Lactobacillus strain regulates emotional behavior and central GABA receptor expression in a mouse via the vagus nerve. Proc Natl Acad Sci USA 2011, 108:16050-16055.

22. Grenham S, Clarke G, Cryan JF, Dinan TG: Brain-gut-microbe communication in health and disease. Front Physiol 2011, 2:94

23. Backhed F, Ley RE, Sonnenburg JL, Peterson DA, Gordon Jl: Host-bacterial mutualism in the human intestine. Science 2005, 307:1915-1920.

24. Ley RE, Turnbaugh PJ, Klein S, Gordon Jl: Microbial ecology: human gut microbes associated with obesity. Nature 2006, 444:1022-1023.

25. Zhang H, DiBaise JK, Zuccolo A, Kudrna D, Braidotti M, Yu Y, Parameswaran P, Crowell MD, Wing R, Rittmann BE, Krajmalnik-Brown R: Human gut microbiota in obesity and after gastric bypass. Proc Natl Acad Sci USA 2009, 106:2365-2370

26. Eckburg PB, Bik EM, Bernstein CN, Purdom E, Dethlefsen L, Sargent M, Gill SR, Nelson KE, Relman DA: Diversity of the human intestinal microbial flora. Science 2005, 308:1635-1638.

27. Caricilli AM, Picardi PK, de Abreu LL, Ueno M, Prada PO, Ropelle ER, Hirabara SM, Castoldi A, Vieira P, Camara NO, et al: Gut microbiota is a key modulator of insulin resistance in TLR 2 knockout mice. PLOS Biol 2011, 9: e1001212.

28. Cummings JH, Pomare EW, Branch WJ, Naylor CP, Macfarlane GT: Short chain fatty acids in human large intestine, portal, hepatic and venous blood. Gut 1987, 28:1221-1227.

29. MCNeil NI: The contribution of the large intestine to energy supplies in man. Am J Clin Nutr 1984, 39:338-342.
30. Zaibi MS, Stocker CJ, O'Dowd J, Davies A, Bellahcene M, Cawthorne MA, Brown AJ, Smith DM, Arch JR: Roles of GPR41 and GPR43 in leptin secretory responses of murine adipocytes to short chain fatty acids. FEBS Lett 2010, 584:2381-2386.

31. Sekirov I, Russell SL, Antunes LC, Finlay BB: Gut microbiota in health and disease. Physiol Rev 2010, 90:859-904.

32. Forsythe P, Sudo N, Dinan T, Taylor VH, Bienenstock J: Mood and gut feelings. Brain Behav Immun 2010, 24:9-16.

33. Ley RE, Backhed F, Turnbaugh P, Lozupone CA, Knight RD, Gordon الر: Obesity alters gut microbial ecology. Proc Natl Acad Sci USA 2005, 102:11070-11075.

34. Turnbaugh PJ, Ley RE, Mahowald MA, Magrini V, Mardis ER, Gordon J: An obesity-associated gut microbiome with increased capacity for energy harvest. Nature 2006, 444:1027-1031.

35. Cani PD, Amar J, Iglesias MA, Poggi M, Knauf C, Bastelica D, Neyrinck AM, Fava F, Tuohy KM, Chabo C, et al: Metabolic endotoxemia initiates obesity and insulin resistance. Diabetes 2007, 56:1761-1772.

36. De Souza CT, Araujo EP, Bordin S, Ashimine R, Zollner RL, Boschero AC, Saad MJ, Velloso LA: Consumption of a fat-rich diet activates a proinflammatory response and induces insulin resistance in the hypothalamus. Endocrinology 2005, 146:4192-4199.

37. Zhang X, Zhang G, Zhang H, Karin M, Bai H, Cai D: Hypothalamic IKKbeta/ NF-kappaB and ER stress link overnutrition to energy imbalance and obesity. Cell 2008, 135:61-73.

38. Milanski M, Degasperi G, Coope A, Morari J, Denis R, Cintra DE, Tsukumo DM, Anhe G, Amaral ME, Takahashi HK, et al: Saturated fatty acids produce an inflammatory response predominantly through the activation of TLR4 signaling in hypothalamus: implications for the pathogenesis of obesity. J Neurosci 2009, 29:359-370.

39. Ropelle ER, Flores MB, Cintra DE, Rocha GZ, Pauli JR, Morari J, de Souza CT, Moraes JC, Prada PO, Guadagnini D, et al: IL-6 and IL-10 anti-inflammatory activity links exercise to hypothalamic insulin and leptin sensitivity through IKKbeta and ER stress inhibition. PLOS Biol 2010, 8:e1000465

40. Duarte Pimentel G, Rosa JC, Santos de Lira F: Differences in diet between the 19th and 21st centuries: could they lead to insulin and leptin resistance and inflammation? Endocrinol Nutr 2011, 58:252-254.

41. Raybould HE: Gut microbiota, epithelial function and derangements in obesity. J Physiol 2012, 590:441-446.

42. Duparc T, Naslain D, Colom A, Muccioli GG, Massaly N, Delzenne NM, Valet $P$, Cani PD, Knauf $C$ : Jejunum inflammation in obese and diabetic mice impairs enteric glucose detection and modifies nitric oxide release in the hypothalamus. Antioxid Redox Signal 2011, 14:415-423.

43. Ding S, Chi MM, Scull BP, Rigby R, Schwerbrock NM, Magness S, Jobin C, Lund PK: High-fat diet: bacteria interactions promote intestinal inflammation which precedes and correlates with obesity and insulin resistance in mouse. PLoS One 2010, 5:e12191.

44. de La Serre CB, Ellis CL, Lee J, Hartman AL, Rutledge JC, Raybould HE: Propensity to high-fat diet-induced obesity in rats is associated with changes in the gut microbiota and gut inflammation. Am J Physiol Gastrointest Liver Physiol 2010, 299:G440-G448.

45. Monte SV, Caruana JA, Ghanim H, Sia CL, Korzeniewski K, Schentag JJ, Dandona P: Reduction in endotoxemia, oxidative and inflammatory stress, and insulin resistance after Roux-en- $Y$ gastric bypass surgery in patients with morbid obesity and type 2 diabetes mellitus. Surgery 2012, 151:587-593.

46. Vinolo MA, Hirabara SM, Curi R: G-protein-coupled receptors as fat sensors. Curr Opin Clin Nutr Metab Care 2012, 15:112-116.

47. Vijay-Kumar M, Aitken JD, Carvalho FA, Cullender TC, Mwangi S, Srinivasan S, Sitaraman SV, Knight R, Ley RE, Gewirtz AT: Metabolic syndrome and altered gut microbiota in mice lacking Toll-like receptor 5. Science 2010, 328:228-231.

48. Henao-Mejia J, Elinav E, Jin C, Hao L, Mehal WZ, Strowig T, Thaiss CA, Kau AL, Eisenbarth SC, Jurczak MJ, et al: Inflammasome-mediated dysbiosis regulates progression of NAFLD and obesity. Nature 2012 482:179-185.

49. Wu GD, Chen J, Hoffmann C, Bittinger K, Chen YY, Keilbaugh SA, Bewtra M, Knights $D$, Walters WA, Knight $R$, et al: Linking long-term dietary patterns with gut microbial enterotypes. Science 2011, 334:105-108.

50. Brun P, Castagliuolo I, Di Leo V, Buda A, Pinzani M, Palu G, Martines D: Increased intestinal permeability in obese mice: new evidence in the 
pathogenesis of nonalcoholic steatohepatitis. Am J Physiol Gastrointest Liver Physiol 2007, 292:G518-G525.

51. Suzuki T, Hara H: Dietary fat and bile juice, but not obesity, are responsible for the increase in small intestinal permeability induced through the suppression of tight junction protein expression in LETO and OLETF rats. Nutr Metab (Lond) 2010, 7:19.

52. Furuse M, Hirase $T$, Itoh M, Nagafuchi A, Yonemura S, Tsukita S: Occludin: a novel integral membrane protein localizing at tight junctions. J Cell Biol 1993, 123:1777-1788

53. Furuse M, Fujita K, Hiiragi T, Fujimoto K, Tsukita S: Claudin-1 and -2: novel integral membrane proteins localizing at tight junctions with no sequence similarity to occludin. J Cell Biol 1998, 141:1539-1550.

54. Martin-Padura I, Lostaglio S, Schneemann M, Williams L, Romano M, Fruscella P, Panzeri C, Stoppacciaro A, Ruco L, Villa A, et al: Junctional adhesion molecule, a novel member of the immunoglobulin superfamily that distributes at intercellular junctions and modulates monocyte transmigration. J Cell Biol 1998, 142:117-127.

55. Gonzalez-Mariscal L, Betanzos A, Nava P, Jaramillo BE: Tight junction proteins. Prog Biophys Mol Biol 2003, 81:1-44.

56. Cani PD, Bibiloni R, Knauf C, Waget A, Neyrinck AM, Delzenne NM, Burcelin R: Changes in gut microbiota control metabolic endotoxemiainduced inflammation in high-fat diet-induced obesity and diabetes in mice. Diabetes 2008, 57:1470-1481.

57. Osbak PS, Bindslev N, Hansen MB: Relationships between body mass index and short-circuit current in human duodenal and colonic mucosal biopsies. Acta Physiol (Oxf) 2011, 201:47-53.

58. Kremen AJ, Linner JH, Nelson $\mathrm{CH}$ : An experimental evaluation of the nutritional importance of proximal and distal small intestine. Ann Surg 1954, 140:439-448

59. Sjostrom L, Peltonen M, Jacobson P, Sjostrom CD, Karason K, Wedel H Ahlin S, Anveden A, Bengtsson C, Bergmark $G$, et al: Bariatric surgery and long-term cardiovascular events. JAMA 2012, 307:56-65.

60. Evans S, Pamuklar Z, Rosko J, Mahaney P, Jiang N, Park C, Torquati A: Gastric bypass surgery restores meal stimulation of the anorexigenic gut hormones glucagon-like peptide-1 and peptide YY independently of caloric restriction. Surg Endosc 2012, 26:1086-1094.

61. Morinigo R, Moize V, Musri M, Lacy AM, Navarro S, Marin JL, Delgado S, Casamitjana R, Vidal J: Glucagon-like peptide-1, peptide YY, hunger, and satiety after gastric bypass surgery in morbidly obese subjects. J Clin Endocrinol Metab 2006, 91:1735-1740.

62. Falken Y, Hellstrom PM, Holst JJ, Naslund E: Changes in glucose homeostasis after Roux-en-Y gastric bypass surgery for obesity at day three, two months, and one year after surgery: role of gut peptides. $J$ Clin Endocrinol Metab 2011, 96:2227-2235.

63. Beckman LM, Beckman TR, Earthman CP: Changes in gastrointestinal hormones and leptin after Roux-en-Y gastric bypass procedure: a review. J Am Diet Assoc 2010, 110:571-584.

64. Danese S, Fiocchi C: Ulcerative colitis. N Engl J Med 2011, 365:1713-1725.

65. Uchino M, Ikeuchi H, Matsuoka H, Matsumoto T, Takesue $Y$, Tomita N Clinical features and management of duodenal fistula in patients with Crohn's disease. Hepatogastroenterology 2012, 59:171-174.

66. Koloski NA, Jones M, Kalantar J, Weltman M, Zaguirre J, Talley NJ: The brain-gut pathway in functional gastrointestinal disorders is bidirectional: a 12-year prospective population-based study. Gut 2012

67. Macfarlane S, Macfarlane GT: Regulation of short-chain fatty acid production. Proc Nutr Soc 2003, 62:67-72.

68. Walker AW, Sanderson JD, Churcher C, Parkes GC, Hudspith BN, Rayment N, Brostoff J, Parkhill J, Dougan G, Petrovska L: High-throughput clone library analysis of the mucosa-associated microbiota reveals dysbiosis and differences between inflamed and non-inflamed regions of the intestine in inflammatory bowel disease. BMC Microbiol 2011, 11:7.

69. Brint EK, MacSharry J, Fanning A, Shanahan F, Quigley EM: Differential expression of toll-like receptors in patients with irritable bowel syndrome. Am J Gastroenterol 2011, 106:329-336.

70. Cario E, Podolsky DK: Differential alteration in intestinal epithelial cell expression of toll-like receptor 3 (TLR3) and TLR4 in inflammatory bowel disease. Infect Immun 2000, 68:7010-7017.

71. Dinan TG, Quigley EM, Ahmed SM, Scully P, O'Brien S, O'Mahony L, O'Mahony S, Shanahan F, Keeling PW: Hypothalamic-pituitary-gut axis dysregulation in irritable bowel syndrome: plasma cytokines as a potential biomarker? Gastroenterology 2006, 130:304-311.
72. Rodriguez-Perlvarez ML, Sanchez VG, Pastor CM, Gonzalez R, Flores El, Muntane J, Camacho FG: Role of serum cytokine profile in ulcerative colitis assessment. Inflamm Bowel Dis 2012

73. Grijalva CG, Chen L, Delzell E, Baddley JW, Beukelman T, Winthrop KL, Griffin MR, Herrinton LJ, Liu L, Ouellet-Hellstrom R, et al: Initiation of tumor necrosis factor-alpha antagonists and the risk of hospitalization for infection in patients with autoimmune diseases. JAMA 2011. 306:2331-2339

74. Wang K, Yuan CP, Wang W, Yang ZQ Cui W, Mu LZ, Yue ZP, Yin XL, Hu ZM, Liu JX: Expression of interleukin 6 in brain and colon of rats with TNBSinduced colitis. World J Gastroenterol 2010, 16:2252-2259.

75. Pavlov VA, Tracey KJ: Neural regulators of innate immune responses and inflammation. Cell Mol Life Sci 2004, 61:2322-2331.

76. Malinen E, Rinttila T, Kajander K, Matto J, Kassinen A, Krogius L, Saarela M, Korpela R, Palva A: Analysis of the fecal microbiota of irritable bowel syndrome patients and healthy controls with real-time PCR. Am J Gastroenterol 2005, 100:373-382.

77. Kerckhoffs AP, Samsom M, van der Rest ME, de Vogel J, Knol J, Ben-Amor K, Akkermans LM: Lower Bifidobacteria counts in both duodenal mucosaassociated and fecal microbiota in irritable bowel syndrome patients. World I Gastroenterol 2009, 15:2887-2892.

78. Frank DN, St Amand AL, Feldman RA, Boedeker EC, Harpaz N, Pace NR: Molecular-phylogenetic characterization of microbial community imbalances in human inflammatory bowel diseases. Proc Natl Acad SCi USA 2007, 104:13780-13785.

79. Rajilic-Stojanovic M, Biagi E, Heilig HG, Kajander K, Kekkonen RA, Tims S, de Vos WM: Global and deep molecular analysis of microbiota signatures in fecal samples from patients with irritable bowel syndrome. Gastroenterology 2011, 141:1792-1801.

80. Cani PD, Neyrinck AM, Fava F, Knauf C, Burcelin RG, Tuohy KM, Gibson GR, Delzenne NM: Selective increases of bifidobacteria in gut microflora improve high-fat-diet-induced diabetes in mice through a mechanism associated with endotoxaemia. Diabetologia 2007, 50:2374-2383.

81. O'Keefe SJ, Ou J, Delany JP, Curry S, Zoetendal E, Gaskins HR, Gunn S: Effect of fiber supplementation on the microbiota in critically ill patients. World J Gastrointest Pathophysiol 2011, 2:138-145.

82. Sanz Y: Gut microbiota and probiotics in maternal and infant health. Am J Clin Nutr 2011, 94:2000S-2005S.

83. McNulty NP, Yatsunenko T, Hsiao A, Faith JJ, Muegge BD, Goodman AL, Henrissat B, Oozeer R, Cools-Portier S, Gobert G, et al: The impact of a consortium of fermented milk strains on the gut microbiome of gnotobiotic mice and monozygotic twins. Sci Transl Med 2011, 3:106ra106.

84. Thomas $L V$, Ockhuizen T: New insights into the impact of the intestinal microbiota on health and disease: a symposium report. Br J Nutr 2012, 107(Suppl 1):S1-S13.

85. Whorwell PJ: Do probiotics improve symptoms in patients with irritable bowel syndrome? Therap Adv Gastroenterol 2009, 2:37-44.

86. Hakansson A, Molin G: Gut microbiota and inflammation. Nutrients 2011, 3:637-682.

87. Zareie M, Johnson-Henry K, Jury J, Yang PC, Ngan BY, McKay DM, Soderholm JD, Perdue MH, Sherman PM: Probiotics prevent bacterial translocation and improve intestinal barrier function in rats following chronic psychological stress. Gut 2006, 55:1553-1560.

88. Mangell P, Lennernas P, Wang M, Olsson C, Ahrne S, Molin G, Thorlacius H, Jeppsson B: Adhesive capability of Lactobacillus plantarum $299 \mathrm{v}$ is important for preventing bacterial translocation in endotoxemic rats. APMIS 2006, 114:611-618.

89. Reimer RA, McBurney MI: Dietary fiber modulates intestinal proglucagon messenger ribonucleic acid and postprandial secretion of glucagon-like peptide-1 and insulin in rats. Endocrinology 1996, 137:3948-3956.

90. Tarini J, Wolever TM: The fermentable fibre inulin increases postprandial serum short-chain fatty acids and reduces free-fatty acids and ghrelin in healthy subjects. Appl Physiol Nutr Metab 2010, 35:9-16.

91. Everard A, Lazarevic V, Derrien M, Girard M, Muccioli GG, Neyrinck AM, Possemiers S, Van Holle A, Francois P, de Vos WM, et al: Responses of gut microbiota and glucose and lipid metabolism to prebiotics in genetic obese and diet-induced leptin-resistant mice. Diabetes 2011, 60:2775-2786.

92. Roelofsen H, Priebe MG, Vonk RJ: The interaction of short-chain fatty acids with adipose tissue: relevance for prevention of type 2 diabetes. Benef Microbes 2010, 1:433-437. 
93. Haska L, Andersson R, Nyman M: A water-soluble fraction from a byproduct of wheat increases the formation of propionic acid in rats compared with diets based on other by-product fractions and oligofructose. Food Nutr Res 2011.

94. Chawla A, Nguyen KD, Goh YP: Macrophage-mediated inflammation in metabolic disease. Nat Rev Immunol 2011, 11:738-749.

95. Oh DY, Talukdar S, Bae EJ, Imamura T, Morinaga H, Fan W, Li P, Lu WJ, Watkins SM, Olefsky JM: GPR120 is an omega-3 fatty acid receptor mediating potent anti-inflammatory and insulin-sensitizing effects. Cell 2010, 142:687-698

96. Cunningham-Rundles $S$, Ahrne S, Johann-Liang R, Abuav R, DunnNavarra AM, Grassey C, Bengmark S, Cervia JS: Effect of probiotic bacteria on microbial host defense, growth, and immune function in human immunodeficiency virus type-1 infection. Nutrients 2011, 3:1042-1070.

97. Compare D, Nardone G: Contribution of gut microbiota to colonic and extracolonic cancer development. Dig Dis 2011, 29:554-561.

98. Pimentel GD, Portero-McLellan KC, Oliveira EP, Spada AP, Oshiiwa M, Zemdegs JC, Barbalho SM: Long-term nutrition education reduces several risk factors for type 2 diabetes mellitus in Brazilians with impaired glucose tolerance. Nutr Res 2010, 30:186-190.

99. Pimentel GD, Arimura ST, de Moura BM, Silva ME, de Sousa MV: Short-term nutritional counseling reduces body mass index, waist circumference, triceps skinfold and triglycerides in women with metabolic syndrome. Diabetol Metab Syndr 2010, 2:13.

100. Kau AL, Ahern PP, Griffin NW, Goodman AL, Gordon Jl: Human nutrition, the gut microbiome and the immune system. Nature 2011, 474:327-336.

doi:10.1186/1475-2891-11-22

Cite this article as: Pimentel et al: Gut-central nervous system axis is a target for nutritional therapies. Nutrition Journal 2012 11:22.

\section{Submit your next manuscript to BioMed Central} and take full advantage of:

- Convenient online submission

- Thorough peer review

- No space constraints or color figure charges

- Immediate publication on acceptance

- Inclusion in PubMed, CAS, Scopus and Google Scholar

- Research which is freely available for redistribution

Submit your manuscript at www.biomedcentral.com/submit
Biomed Central 